\title{
INSERTING STIPULATION PERTAINING TO POLYGAMY IN A MARRIAGE CONTRACT IN MUSLIM COUNTRIES
}

\author{
Raihanah Abdullah \\ Associate Professor at the Department of Shariah and Law, Academy of \\ Islamic Studies, University of Malaya and is currently a Deputy Director of \\ Center for Civilisational Dialogue, University of Malaya.
}

\begin{abstract}
Generally, Islam permits a wife to stipulate any conditions in a marriage contract. The Muslim jurists however differed in determining the validity of certain conditions and terms upon which their marriage is to take place. One of the controversial conditions is that the wife includes a condition pertaining to polygamy in the marriage contract. It is interesting to note that the practice of inserting stipulations pertaining to polygamy is not a new practice or unusual among many Muslims in the Middle East. Therefore, this article seeks to discuss the possibilities to adopt the Hanbalite's principles on this matter in muslim countries where the Shafi'ite school of thought is predominantly followed. This article argued that by allowing the wife to insert stipulations pertaining to polygamy in a marriage contract does not go against Islam. This is because stipulations in the marriage contract are often aimed at preventing such eventuality and also protecting the position of women should it come to prevent.
\end{abstract}

Keywords: Divorce, ta'liq țalāq, Islamic Family Law, stipulations, marriage contract, polygamy. 


\section{A. Introduction}

Generally, all schools of law permit a wife to stipulate any conditions in her marriage contract. However the Muslim jurists differed in determining the validity of such conditions. With this regard, the wife may include a condition in her marriage contract that prohibited her husband for contracting another marriage in her marriage contract. The majority of the jurists have opposed this view, declaring that such a prohibition as invalid. They argued that polygamy was undoubtedly permitted by the Quran and therefore, a stipulation against polygamy in any marriage contract was certainly against the Quran.

For the Hanbalite schools of law, however, inserting a stipulation against polygamy in a marriage contract did not prohibit the husband from entering into another marriage. Such a stipulation entitled the existing wife to file for divorce if the husband violated the stipulation agreed upon. It is interesting to note that the wives in the Hanbalite schools of law are at a better edge. They held the advantage in ascertaining that their husbands do not practice polygamy, for which this right is not given by other schools of laws. Under the Hanbalite school of law, such terms and conditions were considered valid and if the husband somehow or rather violated the conditions agreed upon in the marriage contract; the wife was entitled for divorce by way of talāq tafwid or taläq ta'irq. They argued that every Muslim has to obey every single term and condition that had been agreed together.

However, not all stipulations were enforceable. There were stipulations that could not be carried out as they were found to be harmful to the wives. As an example, if the prospective wife requested her husband to divorce the existing wife as a condition of marriage, then all the jurists agreed that such stipulation was void.

\section{B. Legal Reform}

Legal reform in terms of inserting a stipulation in marriage contract has been adopted in many Middle Eastern countries. This reform has generally allowed the existing wife to insert a wide range of 
stipulations in marriage contract. ${ }^{1}$ The practice of inserting stipulations against polygamy in marriage contracts is not a practice that is new or unusual among many Muslims societies in the Middle East. ${ }^{2}$ However, stipulations against polygamy in the marriage contract are very rare among the Muslims in south and Southeast Asian countries where the Hanafite and Shafi'ite schools of law are predominantly followed in respective region. ${ }^{3}$

As noted by Anderson, the Hanbalite rule allows women to insert a stipulation in their marriage contract. Today it is commonly accepted among upper class families in Jordan and increasingly accepted among all members of society. Studies on husband-wife agreements among several Muslims normally relate the stipulations to divorce. Stipulations in the marriage contract are often aimed at preventing such eventuality and also protecting the position of women should it come to pass. In the context of polygamous marriages it was found that the husband and wife had agreed to insert stipulations against the husband practicing polygamy in the marriage contract. In the event the husband contracts another marriage, then the wife is entitled for divorce. ${ }^{4}$ Abdal Rehim,

1 The wife may stipulate in her marriage contract pertaining to work of place, residence, education or even the right for her to seek divorce in case the husband takes another wife.

2 This can be seen in research done by Lynn Welchman, Beyond the Code: Muslim Family Law and the Shar'i Judiciary in the Palestinian West Bank, (The Hague: Kluwer Law International, 2000), p. 163; Carolyn Fluehr-Lobban, Islamic Law and Society in the Sudan, ( New Jersey: F. Cass, 1986), p. 134; Ziba Mir-Hosseini, “The Delegated Right to Divorce: Law and Practice in Morocco and Iran”, in L. Carroll, \& H. Kapoor (Eds.), Talaq-i-Tafwid: The Muslim Woman's Contractual Access to Divorce, (London: Women Living under Muslim Law, 1996), p. 128; Lisa Wynn, "Marriage Contracts and Women's Rights in Saudi Arabia", in Homa Hoodfar (ed.), Special Dossier: Shifting Boundaries in Marriage and Divorce in Muslim Communities, vol. 1, (London: Women Living under Muslim Laws, 1996), p. 116; Abdal Rehim Abdal Rahman Abdal-Rehim, "The Family and Gender Laws in Egypt During the Ottoman Period”, in Amira El Azhary Sonbol (ed.), Women, the Family, and Divorce Laws in Islamic History, (New York: Syracuse University Press, 1996), p. 96.

${ }^{3}$ It is difficult to find cases where women in Southeast Asian countries insert stipulations in the marriage contract whereby the husband may not take another wife.

${ }^{4}$ See Abdal Rehim Abdal Rahman Abdal-Rehim, "The Family and Gender," pp. 97-106. 
in his study on the use of stipulations in the registered marriage contract in the sixteenth century found that the practice was prevalent among those who reside at larger cities. Normally the stipulation in the registered marriage contract was associated with divorce. If it was established that the husband had violated the stipulation, then the wife has the right to seek divorce without forfeiting her financial rights. It was also found in Abdul Rahim's research, that the stipulation that restricted the husband from contracting another marriage was one of the most popular stipulations used by society at that period of time.

Such a stipulation in the marriage contract that restricts the husband's right to practice polygamy is specifically recognized in many Middle Eastern Countries. ${ }^{5}$ The codified 1917 Ottoman Family Rights Code was the first piece of legislation that had adopted the Hanbalite's rules on inserting stipulations in marriage contracts. This stipulation includes allowing the wife to seek a divorce in case the husband contracts another marriage. Article 38 of this legislation provides that,

"Where a woman stipulates that the husband should not marry another woman and that if he does so she or the second wife would stand for divorce, and that the contract of marriage shall be valid and the condition enforceable".

In this Article it is clear that the wife is given the right to divorce the husband if the husband fails to abide by the terms stipulated in their marriage contract. This provision can be regarded as a protective provision for women against her husband's polygamous intention. This provision in the said code of law did not aim at controlling or abolishing the practice. The opportunity to insert a stipulation against polygamous marriages is however, left to the wife to make the choice and not enforced through the legislation.

The Hanafite school of law has been followed as the basic reference for all laws in several countries in the Middle-East, therefore, inserting a stipulation in a marriage contract is a procedure that is not allowed. However, the opinions of other schools of law have been

${ }^{5}$ Carolyn Fluehr-Lobban, Islamic Law and Society, p. 134; Lisa Wynn, "Marriage Contracts", p. 116. 
taken into account for the purpose of solving current problems concerning family matters. In this matter, the method of takbayyur has been used in which the adoption of the Hanbalite view allows the insertion of a stipulation in the marriage contract in the 1917 Ottoman of Family Rights. This means that the stipulation against polygamy is recognized in legislations in several Muslim countries, in which other than the Hanbalite school of law is predominantly followed.

In 1951, the Jordanian Law of Family Rights 1951 (Qanūn alHuqūq al-A'Aila al-Urdüniyya) was promulgated in Jordan. ${ }^{6}$ There were no differences between the Jordanian Law of Family Rights 1951 and the previous Ottoman Law of Family Rights 1917. This is because under section 21 of the Jordanian Law of Family Rights 1951 provides similar provisions pertaining to giving rights to the wife to seek for the dissolution of her marriage if the husband failed to abide with the stipulation agreed upon in their marriage contract. Later the Jordanian Law of Personal Status 1976 (Qänūn al-Aḥwäl al-Shakhsiyya) repealed the Jordanian Law of Family Rights 1951 after 25 years of its implementation.

The Jordanian Law of Personal Status 1976 still maintains provisions that allow the insertion of the stipulation in the marriage contract whereby the husband should not take another wife. In this stipulation the wife has the right to divorce in a situation where the husband has violated the stipulation. This means that the new family law legislation did not introduce any new provision or reform in relation to polygamy except that the provision in section 21 of the Jordanian Law of Family Rights 1951 guaranteed that the wife's right after divorce would not be lost even though the wife herself was seeking for divorce on the grounds that her husband had violated the condition stipulated in their marriage contract. At the same time, the insertion of such a stipulation is now a rule and no longer a choice for wife. ${ }^{7}$ With the existence of such a procedure that made stipulation obligatory, it

${ }^{6}$ Further discussion on the development of the Islamic Family Law in Jordan see Lynn Welchman, “The Development of Islamic Family Law in the Legal System of Jordan”, International and Comparative Law Quarterly, vol. 37, 1988, p. 868.

7 Welchman Lynn, “The Development”, p. 873. 
showed that the stipulation which gives the wife the right to divorce in case the husband contracts another marriage, can very much benefit the wife and may protect her from any abuse by her husband's polygamous marriage. Such a provision is not to enforce the implementation of the content of the marriage contract but rather to give rights to the wife to seek for judicial dissolution (fasakh) of the marriage by the Qa $\bar{d} \bar{d} .^{8}$

Apart from the more comprehensive law that had been formulated in 1976, the Jordanian Law has yet to include the provisions in which a polygamous marriage is controlled through the court's permission. Although there has been demand from society to regulate rules that empower the courts to grant permission to practice polygamy, the Jordanian legislators did not favour such regulations. According to Welchman, the Jordanian legislators felt unnecessary to review and change the classical position on polygamy since polygamy is not an urgent issue that needs to be solved. ${ }^{9}$ Provisions are still based on the incorporation of terms and conditions in the marriage contract. The law requires the stipulation in the marriage contract in which the husband cannot marry another. In addition to that Section 40 has a provision where a husband is obliged to treat the wives equally and should provide separate accommodation. However, there is no explanation of the consequences that may occur should the husband fail to obey section 40 of the Jordanian Law of Personal Status 1976.

The Syrian Personal Law Code of 1953 provides general provisions that allow the wife to insert a stipulation in her marriage contract. ${ }^{10}$ This general provision in actual fact does not state specifically that the wife has the right to divorce in case the husband violates the stipulation by contracting another marriage. However, such a stipulation was made possible under article 14 of the Syrian Personal Law Code 1953. This article provides that

(1) where a marriage contract is coupled with a condition which is opposed to the essential nature or the purpose of marriage, or

\footnotetext{
8 Ibid., p. 873.

9 Ibid., p. 883.

${ }^{10}$ Syrian Personal Law Code of 1953, Article 14.
} 
which makes obligatory something forbidden by the Shariah, the condition shall be ineffective while the marriage shall be valid.

(2) where a contract is coupled with a condition which stipulates something for the benefit of the wife, it shall be valid and binding the husband, provided that it is not forbidden by the Shariah, does not effect the rights of a third person, and also does not take away any of the husband's legal rights.

(3) where the wife stipulates a condition in the marriage contract which takes away any such right of the husband, or adversely affects a third person's rights, the condition, although not binding the husband, shall be enforceable to the extent of giving the wife a right to seek dissolution of her marriage, if it is violated by the husband.

It is understood from this provision that the law permits the wife to stipulate in her marriage contract that she is entitled for divorce if her husband contracts another marriage. If the wife merely stipulates that her husband cannot marry another woman during the existing marriage, then the wife cannot enforce such stipulation. The wife, on the other hand, has the right to divorce if the husband insisted in contracting another marriage.

For countries stated above, it is clear that inserting stipulations in the marriage contract is a cautionary step for wives who do not agree with the husband's intention to practice polygamy. The absence of such stipulation in the marriage contract would actually give rise to problems for the wife to file for divorce. This is because divorce through talaq is subjected to the husband's pronouncement of the taläq. In that case the wife has an alternative which is, either, divorce through fasakh or khulu'. This means that polygamy per se is not a valid ground for a wife to seek divorce. Under the Moroccan Personal Status Code 1958, a woman who did not insert such a stipulation and the husband does contract another marriage may request for judicial dissolution of her marriage on the ground of harm (darar). On this point Anderson has rightly viewed that a wife whose husband marries another woman can claim that the deprivation and indignity involved in being reduced to the status of a 'co-wife' in a polygamous union itself constitutes such 
an 'injury'. ${ }^{11}$

In Egypt, even though there are no procedures that restrict the practice of polygamy, the amendment of the Egyptian Personal Status (Amendment) Law No. 100, 1985 has introduced provisions that protect women from any abuses arising from polygamy. Efforts to prevent the incidence of abuse is not through the powers of the Q $\bar{a} d \bar{i}$, that is, by preventing polygamy, but on the other hand, giving rights to the existing wife to seek a judicial dissolution of her marriage if her husband takes another wife without the consent of the existing wife even though no conditions existed within the existing marriage contract that the husband would not marry another woman. ${ }^{12}$ If the existing wife decided not to live anymore with her husband in a polygamous marriage, then section 5A of the Egyptian Personal Status (Amendment) Law 1985 provides that the wife has the right to divorce on the ground of injury caused by her husband's taking another wife. This means that polygamous marriage without the consent of the existing wife has been regarded by the legislation as an act of harm to his existing wife. In that case the existing wife has the right for divorce on the ground of harm (darar) subsequent to her husband's polygamous marriage. The existing wife still has such right every time her husband contracts another marriage. A similar right was also provided under the law for the additional wife in case she did not know that her husband has already married at the time they contracted the marriage.

This provision would not compel women to live as co-wife. It is somehow an effective measure for both the existing wife and the new wife to avoid abuses but only after the polygamous marriage had been contracted. The law seems to protect women and ensures that women would not be abused and become victims from polygamous marriages. It is clear that the laws on personal status in Egypt do not at all prevent the husband from practicing polygamy but, on the other hand, the freedom of the husband to practice polygamy has been balanced with

${ }^{11}$ J.N.D. Anderson, "Reforms in the Law of Divorce in the Muslim World", Studia Islamica, vol.xxxi, 1970, p. 44.

${ }^{12}$ The Algerian Family Code 1984 also provides that the existing wife has the right to petition for divorce if her consent was not obtained. See Abdullahi A. AnNaim, Islamic Family Law in a Changing World, (London: Zed Books, 2002), p. 166. 
giving of rights to the wife for divorce for the reason that the husband has practiced polygamy.

The Law has provided that the existing wife's right to divorce on the ground of her husband's taking another wife will lapse if the existing wife does not initiate action for divorce within one year from the date she comes to know about her husband's polygamous marriage. The law gives the existing wife one year to decide whether she agrees to live with her husband in the polygamous union or she will seek divorce. However, if the Q $\bar{a} d \bar{l}$ makes any decision for irrevocable divorce on the grounds of polygamous marriage, the law requires the Q $\bar{a} \underline{d} \bar{i}$ to conduct a reconciliation session/s. This gives an opportunity to both parties to make decision on their marriage. However, if the reconciliation session/s fails to improve the situation then the Qa di $\bar{i}$ will grant the existing wife irrevocable divorce. It can be understood that from this provision, polygamous marriage that is not made known to the existing wife would cause harm (darar). This means that Article 5A of the Egyptian Personal Status (Amendment) Law 1985 is a provision that aims to prevent abuse from occurring. The effort to avoid the occurrence of abuse is not through the authority of the $Q \bar{Q} \bar{a} \bar{i}$ to prevent the practice of polygamy but, on the other hand, to give rights to the existing wife to seek for divorce if her husband takes another wife. ${ }^{13}$

In a case decided in the Egyptian Constitutional Court, the plaintiff, that is the husband, challenged the legal provisions that gave rights to the wife to seek for divorce on the ground of harm subsequent to her husband's taking another wife. ${ }^{14}$ The plaintiff in this case argued that the provision allowing the wife to seek a divorce was violation of the Quranic verse that permits the husband to contract a polygamous marriage and only required the husband to give equal treatment to his

${ }^{13}$ There was also other provision that a wife in a polygamous marriage may initiate divorce in case of harm (darar). Such provision is provided under Algerian Family Code 1984.

${ }^{14}$ High Constitutional Court Decision of 14 August 1994, Al-Jarida al-Rasmiyya, The Official Gazette, Cairo, No. 35, 1/9/1994, Quoted from Oussama Arabi, "Beyond Power: Neo-Shafi ism or the Islamic Constructive Metaphor in Egypt's High Constitutional Court Policy”, Arab Law Quarterly, v.ol. 17, Pt. 4, 2002, p. 343. 
wives. The High Court Judges argued that Article 1 of Law 100 of 1985 did not violate the Quranic verse that permitted the husband to practice polygamy. The court admitted the importance and the benefits of polygamy as a universal human interest. The provision neither prohibited the husband to practice polygamy nor restricted his right. The High Court Judge also recognized the emotional feelings of hatred and jealousy between the wives in polygamous marriages but refused to consider these negative subjective emotions as sufficient to override the benefits of polygamy. ${ }^{15}$

The Judge further argued that the provision did not provide automatic divorce for the existing wife due to her husband's polygamous marriage. The wife has to produce evidence to support her allegation that her husband's polygamous marriage

"would amount to negating the good companionship between them and its basis, and would result in degrading her". ${ }^{16}$

If the court was satisfied that the husband's polygamous marriage had caused harm to the wife which included a court instigated reconciliation process, then only can the court decide to grant judicial divorce to the wife. The court defended Article 1 of Law 100 of 1985 as not repugnant to the general principle of polygamy in Islam. ${ }^{17}$

In connection with allowing the wife to insert a stipulation that the husband may not marry another wife, the High court Judge argued that the provision does not make the lawful unlawful ${ }^{18}$ that is, the provision does not violate the Quranic permission to practice polygamy. An interesting fact found in this case was where the Judge argued that polygamy is not an obligation but it is a revealed permission for the husband to practice polygamy. In that case the husband may not choose to practice polygamy or to confirm his choice by consenting to the stipulation that the husband may not take another wife in the marriage contract without the contract being in contradiction with the Quran ${ }^{19}$

\footnotetext{
${ }^{15}$ Oussama Arabi, "Beyond Power" p. 347.

${ }^{16}$ Ibid., p. 346.

${ }^{17}$ Tahir Mahmood, "Some Recent Changes in the Egyptian Family Law", Islamic \& Comparative Law Quarterly, vol.5, No. 2, 1985, p. 156.

${ }^{18}$ See Oussama Arabi, "Beyond Power, p. 350.

${ }^{19}$ Oussama Arabi, "Beyond Power, p. 351.
} 
Even though efforts have been made to restrict the husband's polygamous marriage through the court's authority in Egypt such a regulation has been criticized. As Nagla Nassar argued that the percentage of polygamy practitioners in Cairo is around 2.8 percent, which is generally considered too low to raise radical legal actions that may lead to serious consequences. ${ }^{20}$

In Article 30 of the Moroccan Code of Personal Status 1958 it provides that if any injustice is to be feared between wives, polygamy is not permitted. This provision actually is a repetition of what is stated in the Quran in verse 3 Surat al-Nisa'. There were no legal restrictions on polygamy but the court may grant judicial divorce to a wife who complains of injury as a result of her husband contracting another marriage. ${ }^{21}$ In Article 35 of the Moroccan Code of Personal Status 1958 it requires that the man has to treat his wives with just and fairness. Legal reforms in Morocco merely involved the codification of family matters in the modern form of legislation while matters relating to polygamy remain in the classical position.

The same situation is also seen in India, Pakistan and Bangladesh. The wife has the right to divorce in the event the husband marries another. This means that the laws have recognized polygamy as a valid ground for divorce. In Itwari v, Asghari, ${ }^{22}$ the court held that taking another wife is constituted as cruelty to the first wife for the purpose of Indian Dissolution of Muslim Marriages Act 1939. The court had given its view on the concept of polygamous marriages. The court held that:

“...Muslim law as enforced in India has considered polygamy as an institution to be tolerated but not encouraged, and has conferred upon the husband any fundamental right to compel the first wife to share his consortium with another woman in all circumstances. A Muslim husband has the legal right to take a second wife even while the first marriage subsists, but if he does so, and then seek the assistance of the

${ }^{20}$ See Nagla Nassar, "Legal Plurality: Reflection on the Status of Women in Egypt", in Baudouin Dupret, Mautits Berger and Laila al-Zwaini (eds.), Legal Pluralism in the Arab World, (The Hague: Kluwer Law International, 1999), p. 203.

${ }^{21}$ J.N.D. Anderson, and N.J. Coulson, "Islamic Law ", p. 66.

22 A.I.R. (1960), All 684. 
Civil court to compel the first wife to live with him against her wishes on pain of severe penalties including attachment of property, she is entitled to raise the question whether the court, as the court of equity, ought to compel her to submit to co-habitation with such a husband. In that case the circumstances in which her second marriage took place are relevant and material in deciding whether his conduct in taking a second wife in itself an act of cruelty to the first".

This judgment showed that the court accepted the action of the husband in taking a second wife represented as an injury in which it could be a defence to any action brought against her for restitution of conjugal rights. ${ }^{23}$

\section{Marriage Stipulations under Islamic Family Law in Malaysia}

Section 22 of Islamic Family Law (State of Selangor) Enactment 2003 provides that

"(1) Immediately after the solemnization of a marriage, the Registrar shall enter the prescribed particulars and the prescribed or other ta'tiq of the marriage in the Marriage Register".

This provision recognized both the prescribed ta'liq as well as any other conditions agreed upon by the spouse. Women should know their rights before they enter into marriage. They can impose certain conditions to secure themselves in future and does not necessarily rely upon the statutory conditions as provided by the law. A preliminary research done on this matter shows that many women do not know that they have the right to insert any kind of stipulations in their marriage contract other than what has been prescribed by the law. The ignorance of such rights due to the fact that inserting stipulations in a marriage contract among the Muslims in Malaysia is not as popular among the Middle Eastern communities.

The form of ta' $\mathrm{i} q$ prescribed by the law for example in many states in Malaysia is as follow:

"I do solemnly declare when I leave my wife for four months Hijrah continuously or more voluntary or with force and I or my representative do not give her maintenance such period whereas she is obedient to

${ }^{23}$ See J.N.D. Anderson, 'Reforms in the Law “, p. 44 
me or I cause hurt to her body, then she makes a complaint to the Shariah court and if I found by the Shariah court to be true, and she gives to the Shariah which received on my behalf a sum of ten ringgit, then she is divorced by way of kbulu"

This standard taliq deals only on three aspects namely: if the husband leaves the wife more than 4 months Hijrah continuously; or if the husband neglects to provide maintenance to his wife or if the husband hurts and abuses his wife. Other than this actions, a wife is not entitled for divorce through $t a$ ' $i q$. Although the pronouncement of ta'liq is voluntary under the Hukum Syara, it has been a practice in every states in Malaysia where the husband is requested to pronounce the prescribed ta'liq upon marriage. In a situation where the husband violates the stated conditions, the wife has the right to claim tala $q$ ta'tiq.

As it is difficult for the wife to obtain divorce on the ground of polygamy per se, thus by stipulating in the marriage contract where the wife has the right to obtain ta'tiq divorce if the husband contracts another marriage is indeed a protective mechanism. The right for the wife to obtain ta'liq divorce was not an automatic divorce but it represented an option to divorce given to the aggrieved wife who is unable to live in polygamous marriages. Such stipulation was not a recent innovation but rather follows the Hanbali's view, which has been adopted in several Middle Eastern Countries. Such stipulation in the marriage contract did not prevent a husband from practicing polygamy but, otherwise, the stipulation merely provided rights to the wife to file for divorce if the husband chooses the practice. Undoubtedly this stipulation did not go against Islamic teachings because it did not prevent something that is allowed in Shari'ab law, that is, polygamy. Therefore, a wife who decided to include this stipulation in the marriage contract must make sure that the wording for the stipulation concerning polygamy did not actually preclude the husband from contracting another marriage.

Many do not agree with this suggestion because they felt that not all of the laws enforced in the other Islamic countries are suitable for enforcement in Malaysia. If in any case the existing wife refuses to accept her husband's polygamous marriage then she could file for 
divorce through khulü. However, many Shari'ah lawyers in Malaysia give the opinion that divorce at the instigation of the wife such as fasakh and kbulü' are particularly difficult to obtain compared to ta'liq. This is due to the fact that the procedure for dissolution of marriage through ta' $i q$ is rather simple compared to fasakh and khulü. This is because in the ta'liq procedure, the court may grant permission for dissolution of marriage if the wife can prove to the court that the husband has violated terms and conditions he agreed upon in their marriage contract. So far that have been no case in Malaysia where a wife filed for divorce based on the tali' $q$ that if the husband marries another woman, the existing wife has the right to file for divorce through ta'tiq.

In Mobd Razali Mat Saman vs Norshidab Nik Man, ${ }^{24}$ the respondent, who the first wife of the appellant (husband), had said to the appellant words to the effect that "If you set foot on the other land a divorce of three talaq would befall me -ta 'liq." The "other land" as was understood by the appellant was the house of the appellant's second wife. The respondent acceded to the ta'liq and responded with he word "yes" twice and followed by "yes I accepted it. During the trial, the appellant (husband) admitted that he had gone to his second's wife house and stayed there overnight. The learned trial judge ruled that a divorce of three talaq had befallen the respondent. The husband appealed and argued that he only acceded to the pronouncement of $t a$ 'ti $q$ in order to muffle the respondent who was then reprimanding him.

The Syariah High Court of Kelantan then held that the word "yes" uttered by the husband was an answer to the wife's words of ta'liq. Since the husband had thereafter gone to his second wife's house, the husband had violated the ta 'liq and therefore no supporting witness evidence is required. The Syariah High court of Kelantan then dismissed the appeal. The decision of the trial court that ruled the divorce of three talaq was affirmed.

From the example above, it shows that the court will confirmed the divorce of one talaq by way of ta'liq if the husband breach of the pronouncement of $t a$ ' $i q$ made during the marriage by marrying another wife.

${ }^{24}$ Criminal Law Journal, Sya, 2004, p. 479. 


\section{Conclusion}

From this discussion, it is clear that legislators are not in accordance with the idea of giving rights to the existing wife to file for divorce when the husband practices polygamy. The wife can only file for divorce if the husband was found to act unjust in the polygamous marriage. In this matter, Hinchcliffe feels that giving rights to the wife to file for divorce due to the husband practicing polygamy is not really that helpful. ${ }^{25}$ This is because, divorce has negative consequences and it provides social stigma for a divorced woman. Hinchcliffe's argument was based on the Indian society in which divorce was not preferred. However, previous researches have shown that, for some Malayisan women, divorce is the better choice than polygamy. Even though there are several opinions on this matter, Badawi's opinion to give a choice to the existing wife as to whether she agrees to remain as one of the wives in the polygamous marriage or not, represents the most equitable opinion that should be considered. ${ }^{26}$ Such an option can be considered as a solution to the wife who feels that she is unable to tolerate her husband's intention to practice polygamy. Therefore it is a high time for Malaysia to recognize stipulations that giving rights for a wife to file for divorce in case the husband takes another wife for the purpose of protecting the existing wife from being abused in a polygamous marriage.

${ }^{25}$ D. Hinchcliffe, "Polygamy in Traditional and Contemporary Islamic Law", Islam and Modern Age, vol. 1, no.3, 1970, p. 35. 1995), p. 28.

${ }^{26} \mathrm{~J}$. A. Badawi, Gender Equity in Islam, (Indiana: American Trust Publications: 


\section{BIBLIOGRAPHY}

Abdal-Rehim, A. A., "The Family and Gender Laws in Egypt during the Ottoman Period", in Amira El Azhary Sonbol (Ed.) Womens, the Family, and Divorce Laws in Islamic History, New York: Syracuse University Press, 1996.

Anderson, J.N.D., "Reforms in the Law of Divorse in The Muslim World", Studia Islamica, No. 3, 1970.

An-Naim, Abdullahi A., Islamic Family Law in a Changing World, London: Zed Books, 2002.

Arabi, Oussama, "Beyond Power: Neo-Shafi'ism or The Islamic Constructive Metaphor in Egypt's High Constitutional Court Policy", Arab Law Quarterly, 17 (4), 2002.

Badawi, Jamal A., Gender Equity in Islam, Indiana: American Trust Publications, 1995.

Carolyn, Fluehr-Lobban, Islamic Law and Society in the Sudan, Totowa, New Jersey: F. Cass, 1986.

Corroll, L., "Drafting a Marriage Contract With a Tafwid Clause: Practical Considerations and Information", in L. Corral, \& H. Kapoor (Eds), Taläq-I-Tafwid: The Muslim Women's Contractual Access to Divorce, London: Women Living Under Muslim Laws, 1996.

Hinchcliffe, D, "Polygamy in Traditional and Contemporary Islamic

Law. Islamic and the Theory of Legal Change", The American Journal of Comparative Law, 42, 1994.

Mahmood, Tahir, "Some Recent Changes in The Egyptian Family Law", Islamic \& Comparative Law Quarterly, vol. 5, no. 2, 1985.

Mir-Hosseini, Ziba, “The Delegated Right to Divorce: Law and Practice in Morocco and Iran", in L. Carroll, \& H. Kapoor (Eds.), Talāq-iTafwid: The Muslim Woman's Contractual Access to Divorce, London: Women Living under Muslim Laws, 1996.

—, Marriage on Trial, London: I.B.Taurus, 2000.

Nassar, N., "Legal Plurality: Reflection on The Status of Women in Egypt”, in B. Dupret, M. Berger, \& L. Al-Zwaini (Eds.), Legal 
Inserting Stipulation Pertaining to Polygamy in Marriage Contract

Pluralism in The Arab World, The Hague: Kluwer Law International, 1999.

Welchman, L., Beyond The Code: Muslim Family Law and The Shari'i Judiciary in The Palestine West Bank, The Hague: Kluwer Law International, 2000.

-, "The Development of Islamic Family Law in The Legal System of Jordan", International and Comparative Law Quarterly, vol. 37, 1998.

Wynn, L., "Marriage Contracs and Women's Rights in Saudi Arabia", Muslim Living Under Muslim Laws Special Dossier, vol. 1, 1996. 